\title{
ISSN 2656-4807 \\ TINJAUAN PERAN IBU RUMAH TANGGA PRESFEKTIF PEREKONOMIAN DOMESTIK DAN GLOBAL
}

\author{
Muhammad Faqihudin \\ Pascasarjana IAI-N Laa Roiba Bogor \\ mudahsukses321@gmail.com
}

\begin{abstract}
Being a housewife is a very big gift for a woman. This gift if used optimally will be a good deed not only in the world but also in the hereafter. However, there are some women who misunderstood the nature so that he took off his responsibilities as a housewife, the principle matters as housewives were abandoned for various reasons including economic reasons. In economic terms, it actually still has room to participate in the global and domestic economy within the boundaries which are certainly not as broad and free as men. This study aims to further explore the role of housewives in domestic and global economics in a qualitative way, in the hope of producing findings that can be useful as needed.
\end{abstract}

Keywords: household ib, domestic, economy, global

\begin{abstract}
ABSTRAK
Menjadi ibu rumah tangga merupakan karunia yang sangat besar bagi seorang wanita. Karunia tersebut bila dimanfaatkan secara optimal akan menjadi amal kebaikan bukan hanya di dunia tapi juga di akhirat. Namun, ada sebagian wanita yang keliru memahami kodrati tersebut sehingga ia melepas tanggung jawabnya sebagai ibu rumah tangga, hal-hal prinsip sebagai ibu rumah tangga ditinggalkan dengan berbagai alasan termasuk alasan ekonomi. Dalam bisa ekonomi sebetunya masih memiliki ruang untuk ikut dalam perekonomian global maupun domestik dalam batasan yang tentu tidak seluas dan sebebas kaum pria. Penelitian ini bertujuan menggali lebih jauh peran ibu rumah tangga dalamperekonomian domestik dan global dengan cara kualitif, dengan harapan menghasilkan temuan yang dapat berguna sesuai kebutuhan.
\end{abstract}

Kata kunci: ib rumah tangga, domestic, ekonomi, global

\section{PENDAHULUAN}

Salah satu misi pokok kehadiran Islam yang paling dominan adalah li raf'i darajat an-nisa' (untuk menjunjung tinggi secara hormat derajat perempuan). hal ini akan nampak jelas apabila merujuk kepada al-Qur'an dan hadis Nabi, selaku sumber pokok hukum dan ajaran Islam,secara cermat dan jernih memahami ayat-ayat al-Qur'an dan Hadis-hadis shohih yang berhubungan dengan kedudukkan perempuan, kemudian 


\section{AS-SYAR'I: Jurnal Bimbingan \& Konseling Keluarga}

mengkomparasikannya dengan apa yang terjadi pada masa-masa sebelum Islam dan ajaran yang ada pada agama lain. ${ }^{1}$

Halnya, menjadi laki-laki atau perempuan adalah takdir yang tidak bisa dibantah dan diingkari oleh seseorang. Jenis kelamin adalah sesuatu yang dibawa sejak lahir. Oleh karena itu, hal ini bersifat alami, kodrati dan tidak bisa berubah. Sedangkan penilaian terhadap kenyataan sebagai laki-laki atau perempuan oleh masyarakat dengan sosial dan budayanya dinamakan dengan gender. ${ }^{2}$

Muhammad Syaltut dalam bukunya al-IslamAqidah wa Syari'ah menyatakan, bahwa perhatian yang begitu besar itu menunjukkan atas suatu kedudukan yang selayaknya perempuan itu ditempatkan menurut pandangan Islam. Sungguh kedudukan yang diberikan Islam kepada perempuan itu merupakan kedudukan yang tidak pernah diperoleh perempuan pada syari'at agama samawi terdahulu dan tidak pula ditemukan dalam masyarakat manusia manapun. ${ }^{3}$

Deskriptif Perempuan

Perempuan dalam al-Qur'an mendapat perhatian sangat istimewa, perhatian yang tidak pernah diberikan kepada siapun selain perempuan. Sebutan perempuan sendiri dalam al-Qur'an ; an-nisa (wanita-wanita), untsa (perempuan), zaujah (istri), umahat (ibu). Istilah lain perempuan secara etimologis berasal dari kata empu yang berarti "tuan", orang yang mahir atau berkuasa, kepala, hulu, yang paling besar. Perempuan berasal dari kata empu yang artinya dihargai. Lebih lanjut Zaitunah menjelaskan, pergeseran istilah dari wanita ke perempuan. Kata wanita dianggap berasal dari bahasa Sanskerta, dengan dasar kata wan yang berarti nafsu, sehingga kata wanita mempunyai arti yang dinafsui atau merupakan objek seks. Jadi secara simbolik mengubah penggunaan kata wanita ke perempuan adalah megubah objek jadi subjek. Tetapi dalam bahasa Inggris wan ditulis dengan kata want, atau men dalam bahasa Belanda, wun dan schen dalam bahasa Jerman. Kata tersebut mempunyai arti like, wish, desire, aim. kata want dalam bahasa Inggris bentuk lampaunya wanted. Jadi, wanita adalah who is being wanted ${ }^{4}$ (seseorang yang dibutuhkan) yaitu seseorang yang diingini.

Kata perempuan lebih dipilih untuk digunakan karena mengandung konotasi yang lebih positif (amelioratif). Sedangkan kata wanita cenderung tidak digunakan disinni

\footnotetext{
${ }^{1}$ As'ad as-Sahmarani,al-Mar'ah fi at-Tarikh wa Syari'ah, Beirut, Dar an-Nafais, 1989, hal 17

2 Ilyas Yunahar, kesetaraan gender dalam alqur,an; studi pemikiran para mufasir, Yoyakarta, Labda Press, 2006, hal 12-13

${ }^{3}$ Syekh Mahmud Syaltut, al-Islam Aqidatun wa Syari'atun,Beirut, 1996, Dar al-Qalam, hlm.227.

4 Zaitunah Subhan, Qodrat Perempuan Taqdir atau Mitos (Yogyakarta: Pustaka Pesantren, 2004), 1, Kamus Besar bahasa Indonesia (Jakarta: Balai Pustaka, 1990), hlm. 448. Herman Saksono, Pusat Studi wanita (http/www.yoho.com, diakses 24 November 2005)
} 


\section{AS-SYAR'I: Jurnal Bimbingan \& Konseling Keluarga}

karena cenderung berkonotadi negative (pejoratif) dan lebih diposisikan sebagaikan sebagai objek. ${ }^{5}$

Firman Allah SWT menyatakan, penciptaan perempuan dan laki-laki berasal dari satu jenis yang sama, " Hai sekalian manusia, bertakwalah kepada Tuhan-mu yang telah menciptakan kamu dari seorang diri, dan dari padanya Allah menciptakan isterinya; dan dari pada keduanya Allah memperkembang biakkan laki-laki dan perempuan yang banyak. dan bertakwalah kepada Allah yang dengan (mempergunakan) nama-Nya kamu saling meminta satu sama lain, dan (peliharalah) hubungan silaturrahim. Sesungguhnya Allah selalu menjaga dan mengawasi kamu," Qs.An Nisa ayat 1.

Pada prinsipnya kedudukan perempuan sangat terkait erat dengan asal-usul penciptaan, pengakuan Allah atas kemuliaan perempuan, hak kehormatan yang dimiliki perempuan dan hak imbalan yang didapatkan perempuan dari Allah. Oleh karena itu, al-Quran menolak pandangan-pandangan yang membedakan lelaki dan perempuan dengan menegaskan bahwa keduanya berasal dari satu jenis yang sama dan bahwa dari keduanya secara bersama-sama Tuhan mengembangbiakkan keturunannya baik yang lelaki maupun yang perempuan. Memang dalam hadis shahih disebutkan bahwa "Saling pesan-memesanlah untuk berbuat baik kepada perempuan, karena mereka diciptakan dari tulang rusuk yang bengkok." (Diriwayatkan oleh Bukhari, Muslim dan Tirmidzi dari sahabat Abu Hurairah). (Shihab,2004:270)

Menurut Ibnu Katsir, bahwa perempuan itu diciptakan dari tulang rusuk, jika engkau hendak meluruskan tulang yang bengkok akan patahlah ia, tetapi engkau dapat menimatinya dalam keadaan bengkok ( Ibnu Katsir Jilid II : 303). Sedangkan Quraish Shihab mengatakan, pengertian tulang rusuk yang bengkok harus dipahami secara majazi dalam arti bahwa hadis tersebut memperingatkan pada laki-laki agar menghadapi perempuan dengan bijaksana" (2004:271) Dengan demikian berarti mengakui kepribadian perempuan sesuai dengan kodratnya.

Secara ringkas Mahmud Syaltut menjelaskan, bahwa tabiat kemanusiaan antara lelaki dan perempuan hampir dapat (dikatakan) sama. Allah telah menganugerahkan kepada perempuan sebagaimana menganugerahkan kepada lelaki. Kepada mereka berdua dianugerahkan Tuhan potensi dan kemampuan yang cukup untuk memikul tanggung jawab dan yang menjadikan kedua jenis kelamin ini dapat melaksanakan aktivitas-aktivitas yang bersifat umum maupun khusus. Karena itu, hukum-hukum Syari'at pun meletakkan keduanya dalam satu kerangka. Yang ini (lelaki) menjual dan membeli, mengawinkan dan kawin, melanggar dan dihukum, menuntut dan menyaksikan, dan yang itu (perempuan) juga demikian, dapat menjual dan membeli, mengawinkan dan kawin, melanggar dan dihukum serta menuntut dan menyaksikan."(Syaltut,1959: 193)

Penjelasan di atas menguatkan argumen bahwa Islam berbeda dengan kontruk sosial dan budaya yang menempatkan perbedaan antara laki-laki dan perempuan telah

\footnotetext{
${ }^{5}$ Hasil MUNAS KOHATI XIX di Palembang, 2008 hal. 49
} 


\section{AS-SYAR'I: Jurnal Bimbingan \& Konseling Keluarga}

melahirkan paham feminisme. ${ }^{6}$ Perbedaan peran perempuan dalam konsep Islam dan sekuler memang sangat signifikan, karena konsep dasar yang saling bertolak belakang. Peran perempuan dalam konsep sekuler selalu berorientasikan pada apa yang bisa dihasilkan dalam bentuk materi, seperti pendapatan, keterwakilan perempuan dalam parlemen, dan lain sebagainya. Padahal, Islam sangat menghormati perempuan baik sebagai anggota keluarga dan anaggota masyarakat. Sebagai keluarga, seorang perempuan memiliki peranan penting, yakni melahirkan, mengasuh, dan mendidik anak.

Hamka ulama harismatik asal Indonesia memberikan pernyataan yang menarik dalam kaitan perempuan ini, "Jika perempuannya baik, baiklah negara, dan jika mereka bobrok, bobrok pulalah negara.mereka adalah tiang, dan biasanya tiang rumah tidak begitu kelihatan. Namun jika rumah sudah condong, priksalah tiangnya. Tandanya tiangnya yang lapuk."7 Dapat disimpulkan, bahwa kontruk sosial dan budaya yang menempatkan perbedaan antara laki-laki dan perempuan telah melahirkan paham feminisme. ${ }^{8}$

Peran ibu rumah tangga

Meminjam definisi ibu rumah tangga dalam buku Ide-Ide Filasafat, bahwa pengertian Ibu rumah tangga adalah seorang wanita yang bekerja menjalankan atau mengelola rumah keluarganya, bertanggungjawab terhadap anak-anaknya, memasak dan menghidangkan makanan, membeli barang kebutuhan keluarga seharihari,membersihkan dan memelihara rumah, memelihara dan menjahit pakaian untuk keluarga dan sebagainya. ${ }^{9}$

Dalam melaksanakan perannya, seorang ibu rumah tangga dalam Islam menduduki peran sebagai hamba Allah Swt, pendamping suaminya dan sebagai ibu bagi anak-anak dan sebagai anggota masyarakat. Sehingga wanita yang betah di rumah dipuji dalam alQur'an," “Dan tinggallah kalian di dalam rumah-rumah kalian dan janganlah kalian berdandan sebagaimana dandan ala jahiliah terdahulu" (QS Al Ahzab: 33

Alasan wanita lebih baik di rumah, menjadi IRT (Ibu Rumah Tangga) karena wanita itu aurat, sedangkan wanita yang betah di rumah inilah yang lebih menjaga diri. Wanita karir begitu bebas bergaul dengan lawan jenis di kantor, tanpa kenal batas. Disebutkan dalam hadis dari 'Abdullah:

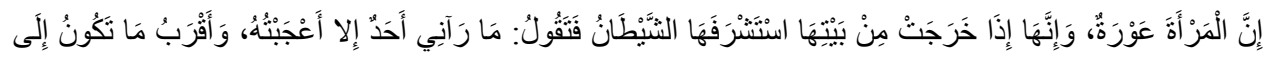

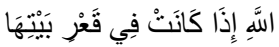

${ }^{6}$ Smith, Linda dan Wiliamm Rapper; Ide-ide Filsafat dan Agama Dulu dan Sekarang; terjemahan Pardono Hadi, Yogyakarta, Penerbit Kanisius, cet V 2004, hal 228

${ }^{7}$ Buya Hamka berbicara tentang perempuan. Jakarta, gema insani, 2014, 15

8 Smith, linda dan wiliamm Rapper;ide-ide filsafat dan agama dulu dan sekarang; terjemahan pardono Hadi, yogyakarta;penerbit kanisius, cet V 2004, hal 228

${ }^{9}$ Macmillan dictionary definision,lihat https://id.m.wikipedia.org. 


\section{AS-SYAR'I: Jurnal Bimbingan \& Konseling Keluarga}

"Sesungguhnya perempuan itu aurat. Jika dia keluar rumah maka setan menyambutnya. Keadaan perempuan yang paling dekat dengan Allah adalah ketika dia berada di dalam rumahnya". (HR. Ibnu Khuzaimah no. 1685 dan Tirmidzi no. 1173.

Alasan lain disebutkan Ath Thobari dalam kitab tafsirnya (6: 692), "Wanita tersebut menjaga dirinya ketika tidak ada suaminya, juga ia menjaga kemaluan dan harta suami. Di samping itu, ia wajib menjaga hak Allah dan hak selain itu."Wanita yang terbaik adalah yang taat pada suami, menunaikan kewajiban sebagai istri dan menyenangkan suami, "Sebab itu maka wanita yang shalih, ialah yang taat kepada Allah lagi memelihara diri ketika suaminya tidak ada" (Qs. An-Nisa': 34). Adapun wanita karir tidak bisa sepenuhnya memenuhi tugasnya sebagai istri dan ibu bagi anak-anak. Hal tesebut sesuai hadis,"Pernah ditanyakan kepada Rasulullah shallallahu 'alaihi wa sallam, "Siapakah wanita yang paling baik?" Jawab beliau, "Yaitu yang paling menyenangkan jika dilihat suaminya, mentaati suami jika diperintah, dan tidak menyelisihi suami pada diri dan hartanya sehingga membuat suami benci" (HR. An Nasai no. 3231 dan Ahmad 2/251). Wanita yang terbaik adalah yang bertanggungjawab untuk mengurus rumah dan anak-anaknya. Sedangkan wanita karir terlalu sibuk pada pekerjaan dan karir, sehingga pendidikan terhadap anak dilalaikan.

Diriwayatkan dari Ibnu 'Umar, Rasulullah Saw bersabda, "Setiap kalian adalah pemimpin dan akan dimintai pertanggungjawaban mengenai kepemimpinannya. Kepala negara adalah pemimpin dan ia akan dimintai pertanggungjawaban mengenai kepemimpinan pada rakyatnya. Kepala keluarga adalah pemimpin bagi keluarganya dan ia akan dimintai pertanggungjawaban mengenai kepemimpinannya tersebut. Seorang wanita menjadi pemimpin di rumah suaminya, ia akan dimintai pertanggungjawaban mengenai hal itu." (HR. Bukhari no. 2409). Dari hadis tersebut menunjukan bahwa wanita yang terbaik adalah yang pandai menerima pemberian suami, begitu pula ridha dengan yang sedikit. Namun ini sulit ditemukan pada wanita karir. Bila gajinya lebih tinggi dari suami, ia akan sulit menghargai pemberian suami yang relatif kecil. Padahal sulit berterima kasih seperti itu yang membuat banyak wanita disiksa di neraka.

Berkhidmat kepada suami dengan melayaninya dalam segala kebutuhankebutuhannya adalah diantara tugas seorang istri. Bukan sebaliknya, istri yang malah dilayani oleh suami. Hal ini didukung oleh firman Allah, "Dan laki-laki itu adalah pemimpin bagi wanita" (QS. An Nisa [4]: 34). Ibnul Qayyim berdalil dengan ayat diatas, jika suami menjadi pelayan bagi istrinya, dalam memasak, mencuci, mengurus rumah dan lain-lain, maka itu termasuk perbuatan munkar. Karena berarti dengan demikian sang suami tidak lagi menjadi pemimpin. Justru karena tugas-tugas istri dalam melayani suami lah, Allah pun mewajibkan para suami untuk menafkahi istri dengan memberinya makan, pakaian dan tempat tinggal. (Lihat Zaad Al-Ma'aad 5/188-199 via Tanbihat, hal. 95, DR Shaleh Al Fauzan). 


\section{AS-SYAR'I: Jurnal Bimbingan \& Konseling Keluarga}

\section{METODOLOGI PENELITIAN}

Penelitian ini menggunakan pendekatan kualitatif deskriptif untuk menghasilkan komprehensip dalam pembahasan. Selain itu dengan mengungkapkan gran teori, teori turunan dan penjelasan penjelasan yang mendukung penelitian.

Analisis peran ibu rumah tangga dalam perekonomian

Dalam bagian ini penelitian akan memberikan analisis dari beberapa pandangan ulama mengenai peran ekonomi seorang ibu rumah tangga baik domestik maupun global. Dikutip dari buku "Tahriru Mar'ah fi'aAshrir Risalah" dalam pengantarnya Yusuf Qordawi meneyebutkan adanya dua kelompok dalam melihat wanita; kelompok pertama, yang baik sangka kepada wanita.kelompok kedua, kelompok yang menjadi musuh wanita. Demikian juga, ditemukan sebagian filosof mendukung keberadaan wanita, menyanjung, serta menyebut-nyebut kelebihan dan keutamaanya dalamkeluarga dan masyrakat.namun, ada juga mereka yang melihat kaum wanita lewat kaca mata hitam pekat sehingga wanita dilihat bagaikan kuman penyakit dan sumber kejahatan di dunia. ${ }^{10}$

\section{HASIL DAN PEMBAHASAN}

Di era globalisasi masih ditemukan penyakit ganas yang melanda alam pemikiran manusia. Banyak permasalahan yang dipecahkan dengan pragmatis tanpa didasarkan dasarkan pada jalan tengah yang dalam terminologi Islam sebagai shirathalmustaqiim (jalan yang lurus). Sehingga masyarakat mengambil keputusan yang ekstriem, ada yang berlebih-lebihan dan ada pula yang menyia-nyiakan kaum perempuan. Kelompok yang menyia-nyiakan dan menyepelekan hak-hak wanita memandang wanita dengan sikap angkuh dan pandangan hina. Menurut mereka,wanita ibarat jerat setan, perangkap iblis yang menggoda manusia. Wanita dianggap mahluk yang kurang akal,wanita sebagi budak atau setengah budak laki-laki,bahkan wanita dianggap seperti sandal yang bisa dilepaskan kapan pun diinginkan.

Sedangkan masyarakat yang kembali seperti masyarakat jahiliyah, wanita tidak diberi hak untuk warisan, mereka mengurung para wanita untuk menuntut ilmu dan keluar untuk bekerja, tidak boleh mengikuti kegiatan masyarakat yang bermanfaat apa pun jenisnya, sehingga sebagian mereka berpandangan bahwa wanita yang sholehah adalah tidak keluar kecuali dua kali; yaitu dari rumah orang tuanya ke rumah suaminya dan dari rumah suaminya ke liang kuburnya. Kelompok yang berlebih-lebihan dalam urusan wanita,sehingga melampaui hukum Allah serta melampau garis fitrah dan akhlak mulia yang telah ditetapkan agama. Jika kelompok pertama tadi menjadi tawanan tradisi Timur yang diwarisi turun temurun, maka kelompok kedua ini menjadi tawanan tradisi Barat.

${ }^{10}$ Abdul Halim Abu Suqqah, Tahriru Mar'ah fi'aAshrir Risalah (terj. Kebebasan Wanita ), Jakarta, Gema Insani Press,1997 


\section{AS-SYAR'I: Jurnal Bimbingan \& Konseling Keluarga}

Yang tepat dikatakan adalah bahwa sebagian besar dari orang -orang yang bersikap ekstrem dan berlebihan dalam meniru Barat adalah sebagai reaksi terhadap orang orang yang bersikap ektrem dan keterlaluan dalam meniru Timur, atau dengan kata lain mereka menjadi tawanan zaman kuno dan zaman modern. Sementara yang dituntut hanyalah tunduk dan patuh kepada petunjuk dan bimbingan agama yang benar dari nabiMuhammad SAW. Karena itu, perlu bersikap yang mencerminkan sifat dan karakter pertengahan Islam yang menghormati wanita dan tidak berlebihan serta tidak mengurangi hak-haknya. Sebagaimana al-Qur'an menyebutkan dalam surat arRahman ayat 8-9, "Dan tegakkanlah keseimbangan itu dengan adil dan janganlah kamu mengurangi keseimbangan itu. Dan bumi telah Dibentangkan-Nya untuk makhluk(Nya)."

Bisa dikatakan kelompok ke-tiga adalah pandangan sebagian kaum Sufi(ektriem) yang mengutamakan perempuan dari yang lainnya, karena menurut para sufi perempuan adalah makhluk dari hasil emanasi Tuhan yang memiliki sifat kelembutan,, Jalaludin Rumi:"perempuan adalah seberkas cahaya Illahi. Dia bukanlah wujud yang menjadi sasaran hasrat nafsu. Dia adalah pencipta, baiknya disebut begitu. Dia bukanlah .$" 11$

Selain hal tersebut di atas, Abd. Hamid dalam bukunya Sumber Daya Manusia yang Produktif menyebutkan, bahwa manusia adalah makhluk hidup yang diantara tabiatnya adalah berfikir dan bekerja. Oleh karena itu, Islam menganjurkan kepada pria dan wanita untuk bekerja. Pekerjaan merupakan salah satu sarana memperoleh rizki dan sumber kehidupan yang layak dan dapat pula bahwa bekerja adalah kewajiban dan kehidupan. ${ }^{12}$

Posisi perempuan sebagai warga negara dengan segala hak dan kewajibannya telah tertuang pada pasal 27 ayat 1 Undang Undang Dasar 1945 yang berbunyi, Segala warga negara bersamaan kedudukannya di dalam hukum dan pemerintahan dan wajib menjunjung hukum dan pemerintahan itu dengan tidak ada kecualinya. Berdasarkan ketentuan tersebut berarti tidak ada perbedaan antara laki laki dan perempuan dimata hukum, semuanya mempunyai hak dan kewajiban yang sama, oleh karenanya posisi perempuan sama dengan posisi laki laki.

11 Jalaludin Rumi, Matsnawi, Kitab I, 2437 ([ed.] .Nicholson, teks, I, 150; Syarah, VII, 155-156), dalam buku, Henry Corbin,'Imajinasi Kreatif Sufisme Ibn 'Arabi”, LKIS, Yogyakarta, Cet,I:Juli 2002, Hal:205

12 Abd. Hamid Mursi, Sumber Daya Manusia yang Produktif, Pendekatan al-Qur'an dan Sains, ,Jakarta: Gema Insani Press, 1996, hal. 35. 


\section{AS-SYAR'I: Jurnal Bimbingan \& Konseling Keluarga}

Halnya, di era glabalisasi peran wanita sangat esensial. Hampir tidak lagi terlihat lagi antara laki laki dan perempuan. Keduanya memiliki status peran, kesempatan yang sangat luas dalam struktur masyarakat modern. Peran yang dimainkan perempuan pada ranah publik dan domestic; peran public, yaitu segala aktivitas manusia yang biasanya dilakukan diluar rumah dan bertujuan untuk mendatangkan penghasilan. Sedangkan, peran domestic, yaitu aktivitas yang dilakukan di dalam rumah dan biasanya tidak dimaksudkan untuk mendatangkan penghasilan, melainkan untuk melakukan kegiatan kerumahtanggaan.

Perempuan yang belum berkeluarga, memiliki peran untuk memikirkan diri dan masa depannya sendiri. Ia berkarir untuk kepentingannya sendiri dan bagaimana bisa berguna bagi masyarakat sekitarnya. Itu artinya, peran seorang perempuan tidak hanya sebagai individu saja, tetapi perempuan juga sebagai makhluk sosial, yakni ia mengabdi kepada agama dan lingkungan masyarakatnya. Contoh: ketika ia harus bekerja. Maka ia akan melakukan perannya sebagai perempuan secara individu atau pribadi dan sebagai seorang pekerja yang bertanggung jawab dengan pekerjaannya. Bagaimana pekerjaan yang dipilihnya itu tidak melanggar aturan agama, tidak melanggar norma sosial maupun hukum yang ada di negeri ini. Ataupun jika perempuan belum bekerja dan masih menjadi mahasiswa, maka ia akan melaksanakan perannya sebagai mahasiswa, sesuai dengan aturan yang ada di masyarakat dan juga di lingkungan sosial seperti kampus dan teman-temannya. Sementara perempuan yang sudah memiliki keluarga, maka seorang perempuan itu juga memiliki peran yang ganda yang bahkan lebih kompleks. Yakni sebagai individu yang senantiasa menyesuaikan diri dengan komponen lingkungan keluarganya serta lingkungan sekitar tempat ia tinggal. Tidak hanya itu saja, seorang perempuan tersebut juga harus menyesuaikan diri terhadap lingkungan pekerjaannya, jika ia wanita karir yang merangkap sebagai seorang ibu. Peran ganda perempuan membawa dampak pada pergeseran nilai dalam keluarga, berupa perubahan struktur fungsional dalam kehidupan keluarga seperti pola penggunaan waktu dan kegiatan untuk keluarga, urusan rumah tangga, pekerjaan, sosial ekonomi, pengembangan diri dan pemanfaatan waktu luang.

Ketika seorang wanita muslimah menikah , maka dia akan memiliki peranan yang khusus dan berbeda dengan pria sebagaimana yang disebutkan dalam ayat Al-Qur'an, "Dan janganlah kamu iri hati terhadap apa yang dikaruniakan Allah kepada sebagian yang lain. (karena) bagi laki-laki ada bagian dari apa yang mereka usahakan, dan bagi para wanita (pun) ada bagian dari apa yang mereka usahakan dan mohonlah kepada Allah sebagian dari karunia-Nya. Sesungguhnya Allah Maha Mengetahui Segala Sesuatu." (Qs. An-Nisaa' , 4:32). Karenanya, seorang istri akan membenarkan Rosulullah dan akan membantu suaminya untuk menyesuaikan dengan prinsip-prinsip syari'ah (hukum Islam) dan memastikan suaminya untuk kembali melaksanakan kewajibankewajibannya, begitu pun dengan kedudukan suami, dia juga harus memenuhi kewajiban terhadap istrinya. 


\section{AS-SYAR'I: Jurnal Bimbingan \& Konseling Keluarga}

Di antara hak-hak lainnya, seorang istri memiliki hak untuk Nafaqah (diberi nafkah) yang berupa makanan, pakaian dan tempat untuk berlindung yang didapatkan dari suaminya. Dia (suami) berkewajiban membelanjakan hartanya untuk itu walaupun jika istri memiliki harta sendiri untuk memenuhinya. Rosulullah saw Bersabda," Istrimu memiliki hak atas kamu bahwa kamu mencukupi mereka dengan makanan, pakaian dan tempat berlindung dengan cara yang baik." (HR. Muslim). Ketika seorang istri menunaikan kewajiban terhadap suaminya, dia (istri) talah melakukan kepatuhan terhadap pencipta-Nya, karenanya dia (istri yang telah menunaikan kewajibannya) mendapatkan pahala dari Tuhan-Nya.

Aisyah RA. suatu kali meriwayatkan tentang kebaikan kualitas Zainab ra,"Zainab adalah seseorang yang kedudukannya hampir sama kedudukannya denganku dalam pandangan Rosulullah dan aku belum pernah melihat seorang wanita yang lebih terdepan kesholehannya daripada Zainab r.a., lebih dalam kebaikannya, lebih dalam kebenarannya, lebih dalam pertalian darahnya, lebih dalam kedermawanannya dan pengorbanannya dalam hidup serta mempunyai hati yang lebih lembut, itulah yang menyebabkan ia lebih dekat kepada Allah".

Wanita di samping perannya dalam keluarga, ia juga bisa mempunyai peran lainnya di dalam masyarakat dan Negara. Jika ia adalah seorang yang ahli dalam ilmu agama, maka wajib baginya untuk mendakwahkan apa yang ia ketahui kepada kaum wanita lainnya. Begitu pula jika ia merupakan seorang yang ahli dalam bidang tertentu, maka ia bisa mempunyai andil dalam urusan tersebut namun dengan batasan-batasan yang telah disyariatkan dan tentunya setelah kewajibannya sebagai ibu rumah tangga telah terpenuhi. Banyak hal yang bisa dilakukan kaum wanita dalam masyarakat dan Negara, dan ia punya perannya masing-masing yang tentunya berbeda dengan kaum laki-laki. Hal ini sebagaimana yang dilakukan para shahabiyah nabi.

Ada banyak contoh inspirasi di masa lalu tentang aktivitas luar biasa dalam ranah publik yang digeluti oleh wanita muslimah. Sebagai contoh kisah seorang wanita yang diceritakan dalam kitab Ath-Taqabat karangan Ibn Sa'id, mengisahkan tentang Ummu Qailah dari Bani Ammar pernah datang kepada Rasulullah SAW untuk meminta petunjuk mengenai pengelolaan jual beli. Istri Rasulullah SAW, Zainab binti Jahsy,dalam riwayat Muslim bahwa Aisyah berkata,,,ternyata yang terpanjang tangannya di antara kami adalah Zainab sebab dia sudah biasa berusaha dengan tangannya sendiri dan bersedekah." alHakim dalamMustadraknya menyebutkan bahwa Zaenab binti Jahsy adalah seorang wanita perajin,ahlimenyamak danmenjahit kulit dan dengan usahanya itu dia besedekah dijalan Allah. ${ }^{13}$ juga aktif bekerja menyamak kulit binatang, menjualnya dan hasil usahanya sebagian disedekahkan. Ada lagi kisah seorang wanita yang pandai menulis bernama Asy-Syifa, yang ditugaskan oleh Khalifah Umar bin Khattab RA sebagai petugas yang mengatur manajemen perdagangan kota Madinah.

${ }^{13}$ Muslim kitab : keutamaan-keutamaan para sahabat, bab :diantara keutamaan Zaenab umulmukminin,jilid 7 hal 144 


\section{AS-SYAR'I: Jurnal Bimbingan \& Konseling Keluarga}

Tidak lupa ibunda Khadijah, istri Rasulullah SAW, yang sangat terkenal dengan kepiawaiannya dalam mengelola perdagangan bahkan sampai level perdagangan lintas negara.

Selain aktivitas perekonomian, tidak sedikit pula wanita muslimah yang sangat menonjol pengetahuannya dalam berbagai bidang ilmu pengetahuan. Aisyah RA adalah contoh wanita muslimah yang sangat dalam pengetahuan agamanya, meriwayatkan banyak hadist serta dikenal kritis dan cerdas. Asy-Syaikhah Syuhrah yang digelari sebagai Fakhr An-nisa (kebanggan perempuan) adalah salah seorang guru dari Imam Syafi'i. Ratu Rukhayah, istri dari Raja Akbar dari dinasti Mughal di India, terkenal karena kemampuannya menguasai banyak bahasa dan kecerdasannya dalam mengelola negara bersama Raja Akbar. Terdapat juga Ummu Salamah yang terkenal cerdas dan berjasa memberikan masukan kepada Rasulullah SAW pada momen Perjanjian Hudaibiyah. Kemudian Ummu Hani' yang sikapnya dibenarkan oleh Rasulullah SAW ketika memberikan jaminan keamanan kepada sebagian orang musyrik.

Peran perempuan dalam perekonomian dalam ajaran Islam berpijak dari kalimat umum dalil Al-Qur'an " "Bagi lelaki bagian yang ia usahakan dan bagi wanita bagian yang ia usahakan" (An-Nisa : 32 ).

أكل أحد طعاما قط خيرا من أن يأكل من عمل يده : Demikian Nabi SAW menyebutkan bahwa "Tiada seorang pun yang makan lebih baik dari orang yang makan dari hasil tangannya sendiri" ( Riwayat, Al-Bukhari, no 1966, Fath Al-bari, 4/306).

Kebanyakan wanita di zaman Nabi dahulu tidak bekerja di luar rumah dan hanya bekerja di sekitar rumahnya saja. Cuma sebagian wanita islam adakalanya bertugas di luar rumah sekali sekali berdasarkan keperluan. Ummu Atiyah sebagai contoh yang bertugas menguruskan jenazah wanita Islam di Madinah, merawat lelaki yang cedera di medan peperangan disamping itu menyediakan makanan buat pejuang-pejuang Islam. Termasuk juga adalah Rufaydah Al-Aslamiyyah, yang merupakan doktor wanita Islam pertama yang mana Nabi SAW menyediakan sebuah kemah khusus di masjid Nabi untuk tujuan merawat pejuang Islam yang cedera ketika peperangan 'Khandaq'.

Demikian juga Ar-Rabaiyyi` bint Mu`awwiz and Umm Sulaim yang bertugas di luar rumah untuk memberi minuman dan makanan kepada pejuang. Ash-Shifa' binti 'Abdullah pula pernah bertugas sebagai guru yang mengajar wanita-wanita islam membaca dan menulis ketika baginda nabi Muhammad SAW masih hidup. Umm Mihjan pula bertugas sebagai pembantu membersihkan masjid nabi sehingga ketika ia meninggal dunia, nabi mencari-carinya dan diberitahu setelahnya, ia telah meninggal dunia. Sebagai penghormatan, baginda Nabi SAW pergi di kuburnya lalu menunaikan solat jenazah buatnya. Selain itu, halifah 'Umar ibn Al-Khattab juga pernah melantik wanita bernama Ash-Shifa' untuk menjalankan tugas al-hisbah atau 'Shariah auditor' di pasar di ketika itu bagi memastikan ia dijalankan menepati Shariah.

Muhammad Uqlah Al-Ibrahim dalam buku Al-Mar'ah Bayna Al-bayt Wal Mujtama wmengatakan wanita boleh berperan dalam perekonomian global dengan syarat-syarat 


\section{AS-SYAR'I: Jurnal Bimbingan \& Konseling Keluarga}

tertentu, diantaranya; ${ }^{14}$ 1) Terdapat keperluan : menyebabkan ia terpaksa keluar dari tanggungjawab asalnya (yaitu peranan utama kepada rumahtangga) seperti : a. Kematian suami dan memerlukan belanja kehidupan. b. Membantu kepada kedua orang tua yang sangat miskin atau suami yang uzur tubuhnya. c. Membantu bisnis suami yang memerlukan banyak tenaga dan biaya. d. Mempunyai keistemewaan yang hebat sehinggakan kemahiran ini sangat diperlukan oleh masyarakat umumnya (spesialis). 2) Semestinya pekerjaan ini sesuai dengan fitrah seorang wanita dan kemampuan fisiknya. 3) Pada saat keluar untuk bekerja harus dengan menutup aurat dan sentiasa menjauhi fitnah di tempat kerja. 4) Kondisi ruang kerjanya tidak berduaduaan(khalwat) dan bercampur baur dengan lelaki (ikhtilat tanpa batas/sering bersinggungan langsung) seperti dalam al-Qur'an surat al-Qasas : 24. 5) Mendapat izin wali atau suami. 6) Dengan bekerjanya sang Istri, tidak menyebabkan terganggu dan terhentinya tanggung jawab di rumah terhadap anak serta suami. (Nazarat Fi Kitab AsSufur, hlm 84).7) Tujuan dan niat utama bekerja bukanlah untuk kesenangan atau hobby maupun keinginan untuk mengumpulkan harta dan niat semata-mata menyaingi lelaki. 8) Harus berhenti sekiranya terdapat keperluan dan kekurangan dalam pendidikan anak-anak. 9) Diniatkan kerjanya dilakukan dalam tempoh waktu tertentu saja dan bukan selama-lamanya. Sepatutnya berhenti segera setelah suami mempunyai kemampuan menanggung seluruh keluarga dengan baik. Kecuali jika mempunyai kualitasi yang amat diperlukan oleh masyarakat umum.

Perempuan yang masuk ke sektor publik tidak harus disertai profesi tertentu seperti berperan sebagai anggota Dewan Perwakilan Rakyat (DPR). Namun peran di sektor publik bisa dilakukan dengan mengikuti kegiatan pengajian, posyandu, dan lainnya. Amar ma'ruf nahi munkar harus dikerjakan bersama-sama. Artinya, baik lakilaki dan perempuan bersama-sama harus mengurus urusan publik maupun domestik.

\section{KESIMPULAN}

Dari uraian di atas dapat disimpulkan bahwa, pertama, minimnya peran perempuan di ranah publik karena implikasi paham ideologis. Kedua, wanita dan ibu rumah tangga dapat melakukan peran dalam perekonomian domestik dan global dengan tetap mengindahkan ketentuan dan syarat-syarat tertentu yang telah dijelaskan di atas.

\section{DAFTAR PUSTAKA}

As'ad as-Sahmarani, 1989. al-Mar'ah fi at-Tarikh wa Syari'ah, Beirut, Dar an-Nafais.

14 ( Nizam Al-Usrah, 2/282 ; Al-Mar'ah Bayna Al-bayt Wal Mujtama', hlm 18) : 


\section{AS-SYAR'I: Jurnal Bimbingan \& Konseling Keluarga}

Ilyas Yunahar, 2006. kesetaraan gender dalam alqur,an; studi pemikiran para mufasir, Yoyakarta, Labda Press.

Syekh Mahmud Syaltut. 1996. Al-Islam Aqidatun wa Syari'atun, Beirut: Dar al-Qalam.

Zaitunah Subhan. 2004. Qodrat Perempuan Taqdir atau Mitos. Yogyakarta: Pustaka Pesantren

Pusat Bahasa Indonesia. 1990. Kamus Besar bahasa Indonesia. Jakarta: Balai Pustaka, hlm. 448.

Herman Saksono. 2005. Pusat Studi wanita (http/www.yoho.com, diakses 24 November 2005)

KOHATI. 2008. Hasil MUNAS KOHATI XIX di Palembang, hal. 49

Smith, Linda dan Wiliamm Rapper. 2004. Iide-ide filsafat dan agama dulu dan sekarang; terjemahan Pardono Hadi, Yogyakarta; Penerbit Kanisius, cet V, hal 228

Buya Hamka. 2014. Berbicara Tentang Perempuan. Jakarta, Gema Insani, 15

Abdul Halim Abu Suqqah, 1997. Tahriru Mar'ah fi'a Ashrir Risalah (terj. Kebebasan Wanita ), Jakarta, Gema Insani Press,

Jalaludin Rumi, Matsnawi. 2002, Kitab I, 2437 ([ed.] .Nicholson, teks, I, 150; Syarah, VII, 155-156), dalam buku, Henry Corbin,"Imajinasi Kreatif Sufisme Ibn 'Arabi', LKIS, Yogyakarta, Cet,I.

Abd. Hamid Mursi. 1996. Sumber Daya Manusia yang Produktif, Pendekatan al-Qur'an dan Sain,

,Jakarta: Gema Insani Press.

Imam Muslim. 2001. Kitab Keutamaan Para Sahabat, bab; Diantara Keutamaan Zaenab umul mukminin, jilid 7.

Nizam Al-Usrah, 2002. Al-Mar'ah Bayna Al-bayt Wal Mujtama', hlm 18) : 